\title{
DIGITALCOMMONS

4-1-2008

\section{Teachers' Preferences on the Qualities and Roles of a Mentor Teacher}

\section{Donetta Cothran}

Indiana University

Nate McCaughtry

Wayne State University, aj4391@wayne.edu

Sara Renee Anderson Smigell

Wayne State University, ai9971@wayne.edu

Alex Garn

Indiana University

Pamela Hodges Kulinna

Arizona State University

See next page for additional authors

\section{Recommended Citation}

Cothran, D., McCaughtry, N., Smigell, S., Garn, A., Kulinna, Martin, J. J., \& Faust, R. (2008). Teachers' preferences on the qualities and roles of a mentor teacher. Journal of Teaching in Physical Education, 27(2), 241-251.

Available at: http://digitalcommons.wayne.edu/coe_khs/26 
Authors

Donetta Cothran, Nate McCaughtry, Sara Renee Anderson Smigell, Alex Garn, Pamela Hodges Kulinna, Jeffrey J. Martin, and Roberta Faust 


\title{
Teachers' Preferences on the Qualities and Roles of a Mentor Teacher
}

\author{
Donetta Cothran, ${ }^{1}$ Nate McCaughtry, ${ }^{2}$ Sara Smigell, ${ }^{2}$ \\ Alex Garn, ${ }^{1}$ Pamela Kulinna, ${ }^{3}$ Jeffrey J. Martin, ${ }^{2}$ \\ and Roberta Faust ${ }^{4}$ \\ ${ }^{1}$ Indiana University; ${ }^{2}$ Wayne State University; ${ }^{3}$ Arizona State University; \\ ${ }^{4}$ Eastern Michigan University
}

Kay (1990) defines mentoring as "a comprehensive effort directed toward helping a protégé develop the attitudes and behaviors (skills) of self-reliance and accountability within a defined environment" (p. 26). Within education, the two most commonly stated purposes of mentoring are teacher induction and career enhancement (Little, 1990). As such, many states have some type of formal induction mentoring program for their new K-12 educators (Boreen, Johnson, Niday, \& Potts, 2000). These kinds of initiatives, however, are not limited to the United States, as mentoring has been proposed as a key professional development strategy in a variety of countries, including the United Kingdom (Capel, 2003) and in Africa (Mtetwa \& Thompson, 2000).

This investigation is grounded in the teacher professional development literature, of which mentoring is one component. Specific to physical education, mentoring has most often been examined from two perspectives, the induction and development of university faculty and $\mathrm{K}-12$ teacher induction (Griffin \& Ayers, 2005). The university faculty mentoring line of research is the smaller of the two with some calls for mentoring programs (e.g., Clark, 2003; Thomas, 1997) but little research, with the exception of Dodds's (2005) work with women's faculty experiences. The teacher induction and socialization literature has revealed the importance of having a supportive relationship during transition to teaching (e.g., Curtner-Smith, 2001; Hardy, 1999, Templin \& Schempp, 1989) but rarely has addressed mentoring specifically. Overall, there is far more theoretical work suggesting the roles that mentors might play in the transition to teaching and what successful mentoring programs might look like, than actual research on mentoring programs.

Many of the mentor models that have been offered are united by two key concepts. The first is that there are specific abilities needed by mentors to be effective. Even a cursory review of mentoring texts will provide any number of characteristics and checklists of mentor capabilities (e.g., Podsen \& Denmark,

Cothran is with the Kinesiology Department, Indiana University, Bloomington IN; McCaughtry, Smigell, and Martin are with Kinesiology, Health, and Sport Studies, Wayne State University, Detroit, MI; Garn is now with the Department of Kinesiology, Louisiana State University, Baton Rogue, LA; Kulinna is with the Education Department, Arizona State University, Mesa, AZ; and Faust is with Health, PE, Recreation \& Dance, Eastern Michigan University, Ypsilanti, MI. 
2000; Zachary, 2000). Most often, mentor knowledge and skills are divided into personal and professional attributes. For example, Stroot et al. (1998) provide a list of interpersonal characteristics (e.g., empathy, respect, warmth, genuineness) and communication skills (e.g., ability to build rapport, active listening) needed by an effective mentor. Brooks's (1996) participants identified similar qualities and rated interpersonal skills as more important than professional experience or subject-specific expertise.

The second key concept underlying many mentoring programs is that a situated, constructivist, adult learning model is used to understand and frame learning events. This perspective suggests that a sophisticated series of mentor skills are needed beyond personal expertise in a certain domain or more general interpersonal likeability. Zachary (2000) suggests five strategies (ask questions, reformulate statements, summarize, listen for silence, and listen reflectively) mentors should use to facilitate protégés' growth and problem solving. Similarly, Boreen et al. (2000) suggest mentors become reflective dialog coaches and use skills like conferring, questioning, mirroring, and reflecting. The key in this mentoring approach is that mentoring programs should place the learner at the center of the process with the mentor's role being one of facilitation, not direct transfer, of knowledge (Zachary, 2000).

Although the general concepts (specific skills are needed and programs should follow adult learning principles) of mentoring are agreed upon at a theoretical level, very little research has been conducted to see if these theorized concepts meet the needs and expectations of the teachers involved. Another limitation of the current knowledge base is that most of the focus has been on somewhat generic mentoring concerns and meeting the needs of initial teacher preparation and induction (Mtetwa \& Thompson, 2000). Varghese and Wilberschied (2002) noted, however, that there is also a significant need to examine nontraditional career entry into teaching as increasing numbers of individuals choose teaching as a second or even third career. Additionally, a significant number of experienced teachers may choose or be required to teach subject matter content areas and/or grades not included in their initial teacher certifications. Even those teachers working within their subject matter area may feel like novices again when faced with a new curriculum or grade levels (Wells, 1993). Research into the possibilities and dynamics of mentoring in these nontraditional circumstances (moving to new subject areas, grade levels, or new curriculum) may prove important for further enhancing what we already know, albeit still quite little, through more traditional new teacher induction research.

The purpose of this investigation, therefore, was to address the gap in professional development literature related to mentoring, specifically as it applies to nontraditional cases, beyond new teacher induction. In particular, we examined teachers' preferences on mentoring characteristics and practices to determine whether nontraditional mentoring (owing to grade level changes, subject area changes, and newly adopt school district curricula) would be consistent with or contradict models of mentoring based primarily on the induction of new teachers. Teachers' perspectives on the characteristics of quality mentoring are a critical area as demonstrated by Dodds's (2005) work with female university faculty, whose perspectives on mentors were far more varied than traditional conceptions. This report is part of a larger investigation that explored a curricular change initiative in a large urban school district and is a companion to another article published in 
JTPE about the same program (see McCaughtry, Kulinna, Cothran, Martin, \& Faust, 2005). This report takes a more phenomenological approach to the investigation of mentoring as we report only teachers' mentoring preferences. We wanted to share, in their own words, how teachers described effective mentoring and then compare that perspective to theorized models.

\section{Methods}

\section{Participants and Setting}

Thirty elementary physical education teachers (12 males and 18 females) volunteered to participate in a mentoring program sponsored by a large urban school district in the U.S. Midwest. The district serves over 150,000 students, most of whom are African American (over 85\%) and qualify for free or reduced lunch (over 70\%) programs. The district faces great challenges in recruiting and retaining teachers. Many teaching positions are filled by personnel without teaching licenses and, of those hired, over half leave the district within the first 5 years. Financial constraints led to the elimination of all teacher professional development 3 years before this investigation. The majority of teachers reported their ethnic background as African American $(n=14)$ or Caucasian $(n=15)$, with one teacher reporting Other. Participants' teaching experience ranged from several months to 37 years $(M=13.56, S D$ $=11.89)$, with mentor teachers having more teaching experience $(M=22.46, S D=$ $10.25)$ than the protégés $(M=5.36, S D=5.71)$. Of the 15 protégé participants, five were first-year teachers, two had teaching experience but were working on their initial certification with emergency certificates, three were certified in other areas and retooling to teach physical education_-including two elementary educators and one language arts teacher. The other five had 1 to 19 years of physical education teaching experience. None of the 15 had experience with the Exemplary Physical Education Curriculum (EPEC) prior to the study.

Each of the 15 experienced mentors was paired with one of the 15 less-experienced protégés. The mentors were selected from the initial pool based on their performance in using the curriculum and their willingness to share those experiences with a protégé. The protégés were selected because of their inexperience with EPEC and their desire to work with a mentor to implement the curriculum. Mentoring pairs were matched by a group of school district and university research team members familiar with the teachers and their schools. Factors considered included teacher skills (e.g., management, content knowledge, program advocacy, understanding school and community context, working with special populations), needs (e.g., generally similar items as those considered under teacher skills), personality, and age, as well as school location and characteristics. All teachers were aware of the purpose of the study and provided informed consent.

\section{Mentoring Program}

The yearlong program provided teachers with several professional development opportunities, including a series of workshops. Both groups of participants attended four workshops. Content differed for mentors and protégés in the first workshop, whereas the remaining three workshops were collaborative in nature. The protégés' 
first workshop focused on learning the EPEC curriculum, whereas the mentors' first workshop focused solely on effective mentoring. Mentor training and opportunities to interact with protégés in structured mentoring opportunities were part of all three remaining workshops. Additionally, teachers had a chance to visit each others' schools, view a video tape of their partners' teaching and communicate weekly via online discussion chat rooms. Details of each of the workshops and other aspects of the program are provided in the McCaughtry et al. (2005) article; therefore, this Methods section will focus more on the philosophical underpinnings of the workshops and program.

In support of the tenets of adult learning theory, this mentoring program was designed to promote the role of the mentor as that of a prompter or facilitator of self-reliance and problem solving and the workshops reflected that focus. Both mentors and protégés were taught problem-solving skills and practiced those at the workshops. In addition, the mentors received training on an observation method focused on reflective practice in a preobservation-observation-postobservation format. Particular attention was given to the effective use of questioning to prompt protégés' problem solving and self-growth, with the mentor as a guide and both groups practiced those skills at workshops. Given the tenets of adult learning (e.g., constructivist, facilitation, not transfer of knowledge) and the experienced nature of the protégés who were much closer in age to their mentor than are traditional novice and veteran pairings, we focused on providing a program that positioned teachers as equals. Accordingly, the mentor skills that we provided emphasis on and training in were largely collaborative, indirect, and facilitative in nature.

For example, three approaches to conferencing were shared with the mentors: nondirective, collaborative, and directive (Glickman \& Bey, 1990). The three vary in the degree of direct guidance given by the mentor. The nondirective approach, as the name implies, is the least direct of the three with protégés assuming much of the responsibility for decision making while the mentor serves as a clarifying and encouraging voice. In the collaborative approach, the problem solving and planning for change are a shared responsibility. The mentor teacher assumes much of the responsibility for new ideas and specific changes to practice in the directive approach. The appropriate approach to take is based on the protégé's needs and developmental level. Given that a majority of the protégés in this project had at least some teaching experience, the mentors were given more practice opportunities with the collaborative and nondirective approaches.

\section{Data Collection and Analysis}

The fifteen mentor teachers were interviewed four times throughout the school year, and their protégés were each interviewed three times. Interviews occurred at the teacher's school and lasted from 45 to $90 \mathrm{~min}$. Topics included were mentoring relationships and curriculum and instructional issues related to EPEC. The conversations were recorded and later transcribed.

The data were examined in a constant comparison and analytic induction process looking for ideas and concepts that seemed most salient to the participants' perspectives (Bogdan \& Biklen, 2003). Care was taken to compare and contrast the data among and across mentor teams, mentors and protégés, protégés at various experience levels, and with regard to the timeline of the program. As categories 
of ideas were developed, they were tested against the data sets to look for similar and dissimilar views. This constant checking and rechecking of data sources and themes eventually resulted in the evolution and refinement of the themes presented in this research note. Trustworthiness measures included a member check of transcripts by participants, negative case searches for disconfirming data throughout data analysis, use of a researcher journal, and an experienced qualitative research as a peer debriefer.

\section{Results}

This section provides an overview of teachers' preferences on mentoring characteristics and practices. To more clearly represent participants' perspectives, direct quotations are initialed with $M$ for mentor and $P$ for protégé. Because teacher preferences were consistent over the course of the data collection period, the interview date is not provided.

\section{Effective Mentor Characteristics}

Both mentors and their protégés consistently reported that contextualized subject matter knowledge and experience, as well as, communication skills were key characteristics of effective mentors.

Contextualized Subject Matter Knowledge and Experience. Subject matter knowledge was a key to being a good mentor, as Sharon's (M) comment illustrates: "They should have knowledge of the program, be expert in whatever it is they're mentoring. They should know what they're doing. If they don't know then they should be able to get the resources and assistance and make it available." Beth (M) concurred and said a key to mentor trait would be "prior knowledge in the subject matter. That's the main thing, prior knowledge." Tina (M) described the kind of mentor characteristics she hoped she would display: "I guess communication skills and a good knowledge base. I guess a mentor will have some sort of solid foundation on where they can give some good info to a person if they are seeking help."

Protégés also noted the importance of a solid knowledge base. Don (P), for instance, hoped for a mentor who was "a person that is knowledgeable of the program, very, very, very knowledgeable of the program." However, the protégés also felt as though their mentors' subject matter knowledge needed to be contextually grounded. This seemed to be particularly the case in this project, as most of the teachers believed their urban environment to be unique and challenging. Mike (P), for example, thought that knowledge of urban school challenges was key: "Knowledge of the subject, that's a big one. It wouldn't be beneficial to anyone if the mentor doesn't know the subject themselves. They also need to have an understanding of the school and surroundings." Protégés were particularly interested in "real-world" knowledge, which for these teachers was always a direct reference to their urban context. Nina $(\mathrm{P})$ explained:

I want real experiences. I don't want those book stories. I told my mentor before that school doesn't get you ready for teaching. I want you to give me real life examples. I want real stuff in real life about what's really going to happen as a teacher so I can know what I'm up against. 
Communication Skills. Both mentors and protégés discussed the need for good relationships keyed by effective communication. Charlene (M) explained, "You try to develop a relationship where you can talk to one another freely. You don't really listen to what someone is saying until you kind of get to know them. A little bond has to be first." LaDonna (M) agreed, "Communication is the big thing to worry about. You need to be a good listener and be available so they can always talk to me." When asked about essential qualities in a successful mentor relationship, Martin (P) replied, "Genuineness, just the ability to communicate and have trust." Jackson (P) had similar views: "They need to listen and help me develop my situation. Probably some give and take from both of us because you have to listen too; you both need to listen really well. Patience too."

A specific communication concern of both groups was the mentor's ability to offer feedback in a positive way. Lisa (M) shared her concerns: "I don't want to hurt him. I don't want to hinder him in any way. I don't want to seem overbearing. I don't want to be too pushy, but I need him to see the importance of it." Charlene (M) agreed, "You can't just dog 'em and say you're bad or whatever. You want to have a lighthearted, 'we're in this together to help the students.'" Carlos (P) shared similar views about mentoring and effective feedback: "Someone who cares about who they are mentoring. Someone that relays the information to give it to you direct, but not in an insensitive way, no one that is going to tear you down."

\section{Direct Mentor Styles}

As previously described, many mentoring programs-including this one-are designed to promote the role of the mentor as that of a prompter or facilitator of self-reliance and problem solving and the mentor workshops reflected that focus. This reflective model did not seem to fit this group of teachers' skills or needs. Rather than prompting protégé problem solving via reflective questioning and problem solving, the mentors most often assumed the role of problem solver. Cathy (M), as an example, talked about the tension she felt between the indirect or collaborative mentor models and her personal experience and preference for the direct approach:

I've had so many student teachers and I did see where maybe I don't do some things where I could like posing questions instead of just giving the answer. When I see something that could have been done more efficiently I tend to just cut right to the chase and say, "Here's what you can do." You know, give specific feedback. I think I'll have trouble with the questions but it is good to get that thinking going. I guess that would help a person because if they can figure out their own problem then that would make them want to change. But it seems to me that if I've got a way that works because I've done it for 10 years, then I guess I just want to share it right away instead of letting them come up with the answer.

Rather than being turned off by the mentors' direct model guidance, the protégés actually expressed a stronger desire for their mentors' direct approaches over the indirect ones. For instance, Jim (P) described that he had hoped his mentor would be more direct than he was: 
I guess I was looking for more of an initiator. Someone explaining to me how and what I need to do to begin to implement the curriculum. I thought that they would be able to help me by actually instructing me to begin to implement the system.

Rather than prompting and guiding the protégés to develop their own strategies to solve their own problems, the mentors most frequently offered answers and solutions to protégés' issues by sharing how they solved similar problems in their own teaching. Both groups of teachers described mentors as "giving" knowledge via "hints" or "tips." Denise $(\mathrm{M})$ described her vision of ideal mentoring as being much more direct than indirect: "It is someone that tries to help by giving them some of their experience, by giving them some of the things that worked for them, giving them tips on things like management or another way of doing things." Charlene (M) explained what she tried to do: "It's helping. It's showing someone how to solve their problem and do it better." Will (M) claimed that directly solving a protégé's problems provided emotional satisfaction for himself as a mentor: "Helping someone out feels good. Being able to transfer my knowledge to someone else and enabling them to do the same thing - that's a rewarding process." Teresa (M) talked about her mentoring: "I give her, like little hints about how to do certain things. I gave her some advice on how to set the gym up and organize the kids, like how to set up lines so that kids aren't waiting while others are playing because she didn't have enough equipment."

The protégés' descriptions matched their mentors' closely as they also talked about the direct transfer of knowledge in their relationships. David (P) described an example of how his mentor had helped him: "He gave me a new walking idea. I was doing circle jog and then instead he said have them partner-jog all on one line and then one person goes and then comes back and the next person goes." Melissa (P) shared a management success she discovered thanks to her mentor: "I asked her what she does and I got this technique she uses. She uses one, two, three, or whatever for them to get quiet and I started using it and she told me some little saying to use and it worked."

At least part of the desire for more direct styles seemed related to the difficult context in which the teachers worked (described in McCaughtry, Barnard, Martin, Shen, \& Hodges Kulinna, 2006; McCaughtry, Martin, Hodges Kulinna, \& Cothran, 2006). Promoting student attendance, engagement, achievement, and proper behavior were major challenges that even experienced teachers struggled with on a daily basis. Under such difficult circumstances, anything that could help right now was wanted and appreciated. Sharon (M) explained, "I shared with him the things that worked for me so that he can get this EPEC lesson in and not be overwhelmed, because it can be overwhelming, so very overwhelming at first." Carlos (P) talked about the time pressures when talking about what a mentor should do, "I look for somebody to be more direct. Don't play when you are trying to make me realize something on my own. Don't make me figure it out myself. Tell me! I don't have time to figure it out, tell me, I want to know." Lynn (P) wanted her mentor to "share some ideas that I might not know because they know what works. Just share anything that makes my job better and makes my job easier, and more fun." 


\section{Discussion}

With the widespread popularity of mentoring programs, it is imperative that we critically examine those programs and the perspectives of the participants involved to maximize their effectiveness in professional development. This investigation provides some initial insights into teachers' perspectives and how those perspectives were similar to and different from commonly theorized models of mentoring.

Both mentors and protégés commented on the need for mentors who possess contextualized subject matter knowledge and experience, as well as effective communication skills (especially supportive and nonthreatening demeanors). In these respects, the physical education teachers' reports largely support previous work in general education with regard to effective mentor characteristics (e.g., Martin \& Rippon, 2003). The widespread concern of both groups for nonthreatening feedback has also been noted previously. Feiman-Nemser (2001) reported that "norms of politeness and the desire for harmony create additional barriers to productive mentoring interactions" (p. 1033). These teachers were closer in age and experience than most mentor-protégé pairings, and, therefore, they may have been even more concerned about collegial relations than teachers might be in a more hierarchical relationship, such as in traditional mentor pairings between a novice teacher and a student teaching supervisor.

Related to communication challenges, Varghese and Wilberschied (2002) suggested that when working with nontraditional "new" teachers like those in this study, there is increased difficulty in defining roles and obligations. All mentoring programs, but particularly those serving nontraditional novice teachers may need to spend time with participants talking about their goals and clearly defining roles and expectations for all involved. For example, we partly assumed that because the age and experience differences between these mentors and protégés was less than those in traditional mentoring program, the mentors would have preferred using the less direct models of mentoring, so as to avoid seeming arrogant or condescending to their protégé colleagues, who already had experience of their own. We also expected that the protégés, with the experiences they already brought to the project, would appreciate a more indirect mentor. It was surprising to find that, instead, the mentors and the protégés appreciated the more direct approach, which positioned the mentor as knower and the protégé as receiver.

Another important finding was that the mentor teams rarely engaged in the theorized conferencing model and collaborative problem solving suggested at the workshops. Rather, the mentor teachers almost always assumed the role of problem solver with little reflective collaboration on possible alternatives. It is unclear why the mentors chose such a direct model; however, there could be at least three possibilities to explain this direct action pattern. First, it is possible that the mentor teachers simply did not have the skills needed to implement a collegial, reflective mentor relationship. As Feiman-Nemser (2001) explained,

most teachers have little experience with the core activities of mentoringobserving and talking with other teachers about teaching and learning. They rarely see another teachers' practice and they have limited opportunities to talk about teaching in systematic and rigorous ways. (p. 1033) 
This may have led the mentor teachers to rely on what they knew best, which was to describe their own teaching behaviors and offer them as a prescription for their protégés. Although the training program these mentors received was more intense and long term than many programs, it may not have been long enough, or the most effective approach, to have allowed teachers to develop new skills needed to mentor.

A second possible explanation is that the mentors had the skills but adjusted their mentoring approach to best meet the needs of their protégés. Despite the fact that many of the protégés had teaching experience, it may be that teaching a new curriculum in such challenging circumstances left little time or energy for the potentially lengthy reflective conferences and problem-solving process. The mentors may have been reflective and responding appropriately to the immediate needs of their protégés and provided direct, immediate problem solving to ensure their protégé's daily survival. Tillman (2005) supports this possible explanation by suggesting that the challenges of teaching in an urban school context may mean that teacher mentors have to assume different roles than they would in different contexts, particularly middle class settings.

Alternatively, perhaps these experienced protégés knew how to think and solve problems to some degree, and this mentoring experience was an opportunity to get some nuts and bolts ideas from more experienced colleagues to supplement the critical thinking they already practiced to a greater or lesser extent. This might illustrate a key difference between traditional new teacher induction mentoring and nontraditional mentoring such as the kind described here. It might, for example, be very important to help a brand-new teacher learn how to think like a teacher and develop skills for solving their own problems. Yet if the teachers being mentored have already spent some time teaching, then the mentoring might be equally helpful but in a different way. Instead of helping them learn how to think, they might find it more useful to know what to think because they have already started developing how to solve problems.

Last, Feiman-Nemser and Parker (1993) also suggested that how mentors define their own role and the time they have available to mentor influences their approach. There might be two issues to consider here. The mentor may have deeply ingrained notions about learning, and how anyone learns best. Therefore, in this case, although the mentors were presented with an alternative way of helping their protégés learn, they may have discarded it because they believed that more direct approaches to teaching lead to better and more long-lasting learning than the facilitation approach. Or the mentors may have simply made a cost-benefit analysis related to their own time commitment to helping a newer teacher. The mentors may have felt just as overwhelmed in their day-to-day teaching, so they adopted the direct mentoring model because it fit within their allotted time constraints. It may not have been that they believed the direct method to be better than the indirect method, but that the direct methods would fit into their time constraints better than the seemingly lengthier facilitation modes. Clearly, future research should explore this area and why mentors choose one conferencing approach over another. 


\section{Final Thoughts and Future Directions}

The widespread use of mentoring programs in education has not been paralleled with widespread research on its use and that is a serious problem. Does mentoring work? There is some evidence that at least some programs are effective in reducing teacher attrition (Odell, 1992) and providing teachers with increased feelings of support and classroom assistance (Ehrich, Hansford, \& Tennent, 2004). We do not know, however, whether those same positive trends are true for physical educators. Hudson (2004) suggests that mentoring is subject matter specific, so we cannot assume that what works in general education can be directly transferred to physical education. This investigation contributes to that knowledge base as well as serving as a starting point for future research. Certainly more information is needed on how participants see their roles and how those perspectives develop. Additionally, we need to know why mentors choose to use direct, collaborative, or indirect mentoring methods and how those decisions are influenced by their context. Perhaps the most important prompt for future research and programming is that participants' perspectives must be explored and considered. This group of 30 teachers "made sense" of the program in their unique way based on their past and current experiences. Only by understanding that meaning-making process can one then begin to understand the program and its outcomes. Our call then is for less emphasis on theories, models, and suggestions for mentoring programs, and more emphasis on data-based research on whether and how these theories, models, and programs work.

\section{References}

Bogdan, R.C., \& Biklen, S.K. (2003). Qualitative research for education: An introduction to theory and methods (4th ed.). New York: Allyn and Bacon.

Boreen, J., Johnson, M.K., Niday, D., \& Potts, J. (2000). Mentoring beginning teachers: Guiding, reflecting, coaching. Portland, ME: Stenhouse.

Brooks, V. (1996). Mentoring: The interpersonal dimension. Teacher Development, 5, $5-10$.

Capel, S. (2003). Responsibilities of subject mentors, professional mentors and link tutors in secondary physical education initial teacher education. Mentoring and Tutoring, 11, 131-151.

Clark, J. (2003). The changing role of mentoring the future professoriate with special attention to being a low-consensus discipline. Quest, 55, 51-62.

Curtner-Smith, M.D. (2001). The occupational socialization of a first-year physical education teacher with a teaching orientation. Sport Education and Society, 6, 81-105.

Dodds, P. (2005). PETE women's experiences of being mentored into postsecondary faculty positions. Journal of Teaching in Physical Education, 24, 344-367.

Ehrich, L.C., Hansford, B., \& Tennent, L. (2004). Formal mentoring programs in education and other professions: A review of the literature. Educational Administration Quarterly, 40, 518-540.

Feiman-Nemser, S. (2001). From preparation to practice: Designing a continuum to strengthen and sustain teaching. Teachers College Record, 103, 1013-1055.

Feiman-Nemser, S., \& Parker, M. (1993). Mentoring in context: A comparison of two U.S. programs for beginning teachers. International Journal of Educational Research, 19, 699-718. 
Glickman, C.D., \& Bey, T.M. (1990). Supervision. In W. Robert Houston (Ed.), Handbook of research on teacher education (pp. 549-566). New York: Macmillan.

Griffin, L.L., \& Ayers, S.F. (2005). Introduction-The roles and process of mentoring. Journal of Teaching in Physical Education, 24, 297-301.

Hardy, C.A. (1999). Preservice teachers' perceptions of learning to teach in a predominantly school-based teacher education program. Journal of Teaching in Physical Education, $18,175-198$.

Hudson, P. (2004). Specific mentoring: A theory and model for developing primary science teaching practices. European Journal of Teacher Education, 27, 139-146.

Kay, R. (1990). A definition for developing self-reliance. In T.M. Bey \& C.T. Holmes (Eds.), Mentoring: Developing successful new teachers (pp. 25-38). Reston, VA: Association of Teacher Educators.

Little, J.W. (1990). The mentor phenomenon and the social organization of teaching. Review of Research in Education, 16, 297-351.

Martin, M., \& Rippon, J. (2003). Teacher induction: Personal intelligence and the mentoring relationship. Journal of In-Service Education, 29, 141-162.

McCaughtry, N., Barnard, S., Martin, J., Shen, B., \& Hodges Kulinna, P. (2006). Teachers' perspectives on the challenges of teaching physical education in urban schools: The student emotional filter. Research Quarterly for Exercise and Sport, 77, 486-497.

McCaughtry, N., Kulinna, P.H., Cothran, D.J., Martin, J., \& Faust, R. (2005). Teachers mentoring teachers: A view over time. Journal of Teaching in Physical Education, 24, 326-343.

McCaughtry, N., Martin, J., Hodges-Kulinna, P., \& Cothran, D.J. (2006). Emotional dimensions of teacher change. Journal of Teaching in Physical Education, 25, 99-119.

Mtetwa, D.K., \& Thompson, J.J. (2000). The dilemma of mentoring in mathematics teaching: Implications for teacher preparation in Zimbabwe. Journal of In-Service Education, 26, 139-152.

Odell, S.J. (1992). Teacher mentoring and teacher retention. Journal of Teacher Education, 43, 200-204.

Podsen, I.J., \& Denmark, V.M. (2000). Coaching and mentoring first-year \& student teachers. Larchmont, NY: Eye on Education.

Stroot, S., Keil, V., Stedman, P., Lohr, L., Faust, R., Schincariol-Randall, L., et al. (1998). Peer assistance and review guidebook. Columbus, $\mathrm{OH}$ : Ohio Department of Education.

Templin, T.J., \& Schempp, P.G. (1989) (Eds.), Socialization into physical education: learning to teach, Indianapolis, Ind., Benchmark.

Tillman, L.C. (2005). Mentoring new teachers: Implications for leadership practice in an urban school. Educational Administration Quarterly, 41, 609-629.

Thomas, J. (1997). Vision and leadership for selecting and mentoring new faculty in higher education. Journal of Physical Education, Recreation, and Dance, 68(5), 41-47.

Varghese, M.M., \& Wilberschied, L. (2002). Reconsidering the novice/expert dichotomy in the K-12 mentor-mentee relationship. Journal of In-Service Education, 28, 23-33.

Wells, G. (Ed.). (1993). Changing schools from within: Creating communities of inquiry. Portsmouth, NH: Heinemann.

Zachary, L.J. (2000). The mentor's guide. San Francisco, CA: Jossey-Bass. 